\title{
Verification of traffic emission factors using measurements in a short tunnel in the Czech Republic
}

\author{
Katerina MANEVA MITROVIKJ* and František SKÁCEL \\ Department of Gaseous and Solid Fuels and Air Protection, University of Chemistry and Technology Prague, Technická \\ 5, 166 28, Prague, Czech Republic \\ *Corresponding author; email: Katerina.Maneva@vscht.cz,
}

Received: July 24, 2018; accepted: May 29, 2019

\begin{abstract}
RESUMEN
El transporte por carretera es una de las principales fuentes de emisión de óxido de nitrógeno al aire. Se ha observado que el impacto del crecimiento en las emisiones de $\mathrm{NO}_{\mathrm{x}}$ está relacionado con la intensidad del tráfico en carreteras, y se han desarrollado diversos tipos de modelos de emisión para evaluarlo. Sin embargo, son pocos los modelos de emisión que se han desarrollado usando mediciones de concentraciones ambientales de $\mathrm{NO}_{\mathrm{x}}$. Los sitios más convenientes para representar mediciones en condiciones realistas son los túneles de carreteras. Este artículo presenta una comparación de cálculos de emisiones de $\mathrm{NO}_{\mathrm{x}}$ del modelo HBEFA y emisiones de $\mathrm{NO}_{\mathrm{x}}$ obtenidas en un túnel corto de la República Checa. Se realizaron mediciones simultáneas de concentraciones de $\mathrm{NO}_{\mathrm{x}}$ y de la intensidad del tráfico en el túnel Zeleny most de la República Checa. El trabajo experimental arrojó resultados fiables con evidencia estadística de la mutua correlación entre el nivel de $\mathrm{NO}_{\mathrm{x}}$ y la intensidad del tráfico en esa sección del túnel. Se aplicaron los factores de emisión del modelo HBEFA para transporte por carretera y se compararon con los resultados obtenidos de múltiples campañas de mediciones en la República Checa. Se encontró que las emisiones de $\mathrm{NO}_{\mathrm{x}}$ calculadas diferían de las medidas, ya que sobreestimaban las producidas por vehículos ligeros y subestimaban las producidas por vehículos pesados.
\end{abstract}

\begin{abstract}
Road transportation activities are major contributors of nitrogen oxides emissions to the air. The impact on the growth of $\mathrm{NO}_{\mathrm{x}}$ emission levels is found to be strongly correlated with the traffic intensities on highways. Various types of emission models performing emission assessment of traffic-related pollutants have been developed, but few of them were developed by using real-world measurements of $\mathrm{NO}_{\mathrm{x}}$ concentrations in ambient air. The most convenient sites to perform measurements in real-world conditions are road tunnels. This paper presents a comparison of HBEFA model $\mathrm{NO}_{\mathrm{x}}$ emission calculations and $\mathrm{NO}_{\mathrm{x}}$ emission measured in a short tunnel in the Czech Republic. Simultaneously, measured time-resolved $\mathrm{NO}_{\mathrm{x}}$ concentration and traffic activity counting were performed in the Zeleny most tunnel in the Czech Republic. The experimental work yielded reliable results of the mutual correlation of $\mathrm{NO}_{\mathrm{x}}$ level and traffic intensity in the tunnel section with statistical evidence. Emission factors from HBEFA emission model for road transport were applied and compared with the results from several measurement campaigns in the Czech Republic. It was found that calculated $\mathrm{NO}_{\mathrm{x}}$ emissions differed from measured $\mathrm{NO}_{\mathrm{x}}$ emissions due to the overestimation of light vehicles emissions and underestimation of high-duty vehicles emissions.
\end{abstract}

Keywords: $\mathrm{NO}_{\mathrm{x}}$ emissions, emission models, emission factors, traffic intensity, tunnel measurement. 


\section{Introduction}

Processes and activities involving combustion such as transportation, power plants and industrial activities emit a large scale of atmospheric pollutants. Motor vehicle traffic is the main contributor to road traffic emissions in the ambient air. Appropriate indicators of this environmental burden are nitrogen oxides. Due to human activities, about $40 \%$ of the total $\mathrm{NO}_{\mathrm{x}}$ emissions are released from road activities, $25 \%$ from power plants and the rest from other anthropogenic industrial and commercial processes (EEA, 2014). $\mathrm{NO}_{\mathrm{x}}$ are a group of criteria air pollutants that express the total sum of $\mathrm{NO}$ and $\mathrm{NO}_{2}$ (Leighton, 1961; Atkinson, 2000).

$\mathrm{NO}_{\mathrm{x}}$ do not directly influence the Earth's radiative balance (Prather, 2001). However, they are catalysts of tropospheric $\mathrm{O}_{3}$ formation (Sjödin et al., 1994; Manahan and Manahan, 2009; Seinfeld and Pandis, 2016), major components of photochemical smog and partly responsible for the creation of acid rain (Chang and Suzio, 1995; Atkinson, 2000; Menz and Seip, 2004). Produced by nitrogen and oxygen at high temperatures, $\mathrm{NO}$ and $\mathrm{NO}_{2}$ are highly reactive gases. $\mathrm{NO}$ is predominantly emitted from the exhaust systems of the combustion engines (Seinfeld and Pandis, 2016). However, NO in the atmosphere during a short time is oxidized to $\mathrm{NO}_{2}$ (Nielsen et al., 1996; Carslaw and Beevers, 2005). The ratio of $\mathrm{NO}$ and $\mathrm{NO}_{2}$ concentrations across highways is defined by many factors such as ozone concentration levels, concentration of fine aerosol particles in the air (Sjödin et al., 1994; Ollinger et al., 2002; Pirjola et al., 2006; Beckerman et al., 2008), road distance (Chen et al., 2003; Costabile and Allegrini, 2007; Gilbert et al., 2007; Wang et al., 2011; Pattinson et al., 2014; Sayegh et al., 2016), and catalyst-equipped vehicles with advanced emission control technologies assistance (Sawyer et al., 2000; Wang et al., 2012), among others.

$\mathrm{NO}_{\mathrm{x}}$ play a substantial role in the Earth's atmosphere due to their detrimental effect. In the vicinity of motorways, $\mathrm{NO}_{\mathrm{x}}$ concentration levels may exceed the ambient air quality guidelines and thus have harmful effects on the environment and human health (Brunekreef and Holgate, 2002). As a result of the fast transformation of $\mathrm{NO}$ to $\mathrm{NO}_{2}$, harmful effects are usually attributed to the presence of the later (Last et al., 1994). Average measured $\mathrm{NO}_{2}$ concentration levels depend on meteorological conditions and wind direction but mostly on the distance of the measurement site from highways (Lippmann, 1989; WHO, 2000; Gilbert et al., 2003; Kim and Guldmann, 2011).

The estimation of vehicle emissions has become a notable discussion in the last decades due to the continuous growth of vehicle transportation and its increasing demand. Therefore, numerous emission models have been established for traffic emissions assessment. Emission models are used to estimate pollutant emission levels by calculating road traffic emissions. Emission models are based on the implementation of different parameters, i.e. vehicle and fuel types, driving patterns, fuel consumption, etc., in order to provide emission factors (EFs), which express the emitted mass of a pollutants per driven distance and amount of fuel or energy consumed (Borge et al., 2012; Franco et al., 2013). Vehicle categories and characteristics, emission control technology implementation, operating conditions and fuel consumption are crucial parameters for EFs determination (Smit et al., 2010). There are different models that make possible EFs calculation. Depending on the model the parameters required to determine EFs can be traffic scenario, average traveling speed, second-by-second vehicle data to derive emission information for the complete driving profile or second-by-second vehicle activity parameters of engine power determination (Scora and Barth, 2006; Hausberger et al., 2009; Franco et al., 2013).

In the last few decades, a series of mathematical modeling programs for traffic-related pollutants emissions were established. The first models were created with the initiative of the US Environmental Protection Agency (US-EPA) starting with the primary model AP-42 Compilation of Air Pollutant Emission Factors, published by EPA in 1972. This model compiled emission factors for more than 200 air pollution source categories, including road transport. Subsequently a specialized MOBILE vehicle emission factor model was created considering three primary exhaust pollutants $\left(\mathrm{HC}, \mathrm{CO}\right.$ and $\left.\mathrm{NO}_{\mathrm{x}}\right)$, different vehicle categories (passenger cars, trucks, buses and motorcycles) that use gasoline, diesel or natural gas for combustion, for the years starting from 1952 to 2050 . The MOBILE model was gradually expanded until the year 2010 to MOBILE6.2. Afterwards, the MOBILE 6.2 model was replaced by the MOVES (Motor Vehicle Emission Simulator) model 
as the EPA's official emissions model (US-EPA, 2010, 2016). Since then, a number of similar emission inventory programs such as EMFAC, CMEM, originated in the US and Canada, have been created (Scora and Barth, 2006; Barth et al., 2014; US-EPA, 2015).

Numerous emission models were created in Europe for the estimation of pollutants emissions. Most of these models are based on the Gaussian air pollutant dispersion model in the vicinity of linear emitters (Kukkonen et al., 2001). From these models, the mathematical model Handbook of Emission Factors for Road Transport (HBEFA) stands out distinctly. The model was originally developed upon an initial collaboration between the German, Swiss and Austrian agencies for environmental protection. Subsequently, similar agencies from Sweden, Norway and the Joint Research Centre of the European Commission supported the HBEFA. The first HBEFA model (v. 1.1) was published in 1995, providing average emission factors for Germany and Switzerland. From the year 2010, the updated HBEFA 3.1 model provided data for Germany, Switzerland, Austria, Sweden and Norway. The currently available version from June 2014, is HBEFA 3.2. In addition to the previous countries, this model includes also emission factors for France (Keller and Wüthrich, 2014). The HBEFA emissions model was developed based on results of exhaust gas measurements with dynamometric tests of light-duty vehicles (LDV) and heavy-duty vehicles (HDV), including also dynamometric test measurements of LDV and HDV vehicles from real world driving patterns. These procedures made possible to obtain results that correspond to realistic traffic scenarios with the highest possible degree of accuracy.

Within the project of the Ministry of the Environment of the Czech Republic (MŽP ČR VaV/740/3/00) an authorial team from the University of Chemistry and Technology of Prague, ATEM and DINPROJEKT, created the MEFA v.02 model program (ENVIS, 2009). The currently improved version was developed in 2013 and is available as MEFA 13. This model was assembled using already acquired and verified vehicle emissions data of tests performed in the European Union countries, primarily the application of the aforementioned HBEFA model (Skácel and Tekáč, 2014). These data were supplemented using the results of specific emission tests for the characteristic vehicle fleet of the Czech Republic.
Despite the successful development of the mathematical models for road traffic emissions, the calculated results obtained by the application of EFs and the measurement results of the actual concentration of traffic pollutants cannot be considered as identical, which has been confirmed by several studies that performed measurements with minimal influence of external environmental factors (i.e., meteorological conditions could be left out). For this purpose, road tunnels are very suitable.

Tunnel studies were performed in the Van Nuys tunnel in California to verify the models MOVES2010a, MOBILE6.2, and EMFAC2007 (Fujita et al., 2012); the Gubrist tunnel in Switzerland, to verify the HBEFA2.1 model (John et al., 1999; Colberg et al., 2005a); and the Plabutsch tunnel in Austria, to verify the HBEFA1.2 model (Hausberger et al., 2003; Colberg et al., 2005a). The study in the Van Nuys tunnel, based on the comparison of three models, resulted with higher calculated $\mathrm{NO}_{\mathrm{x}}$ emission factors than the measured $\mathrm{NO}_{\mathrm{x}}$ EFs from the tunnel experiment $(\mathrm{Fu}-$ jita et al., 2012). The results obtained by using each model differed considerably. However, the measured NOx EFs corresponded the most with MOBILE6.2 model EFs and least with EMFAC2007 EFs (Fujita et al., 2012). In addition, an overestimation of $\mathrm{NO}_{\mathrm{x}}$ emission factors from HBEFA2.1 (over $50 \%$ for LDV and $15 \%$ for HDV) was obtained in the study of the Gubrist tunnel (Colberg et al., 2005b). However, in the study of the Plabutsch tunnel, the modeled $\mathrm{NO}_{\mathrm{x}}$ emission factors for HDV were significantly underestimated compared to the measured results (Hausberger et al., 2003). These facts led to a series of verification measurements carried out in a very short tunnel in the Czech Republic, whose main objective was the validation of a mathematical model for the estimation of real road traffic emissions.

\section{Experiment}

\subsection{Sampling site}

The measurements of $\mathrm{NO}_{\mathrm{x}}$ emissions were performed in Zeleny most (short tunnel), which is depicted in figure 1. This tunnel is located on Highway D11 in the Pardubice region, approximately $72 \mathrm{~km}$ east of Prague. Zeleny most is single-bore tunnel with two lanes of traffic in each direction, a length of $77 \mathrm{~m}$ and a cross area of approximately $350 \mathrm{~m}^{2}$ (Fig. 2). 


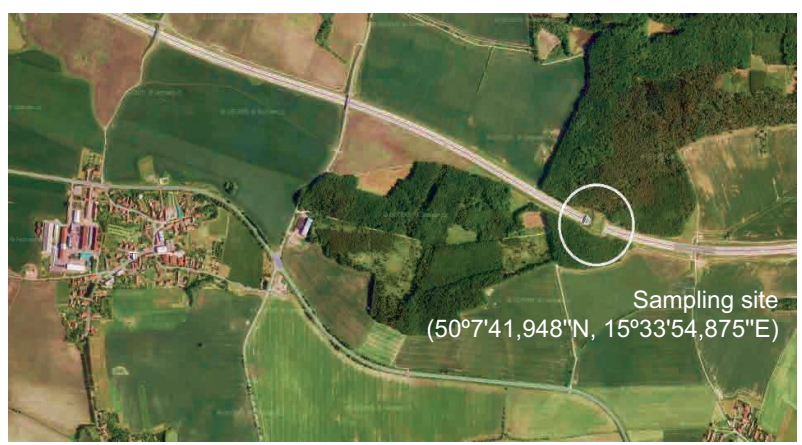

Fig. 1. Sampling site for $\mathrm{NO}_{\mathrm{x}}$ determination.

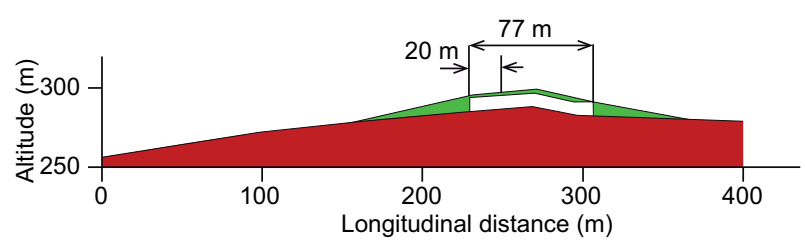

Fig. 2. Longitudinal section of the road-tunnel (Zeleny most) general profile.

This section of the D11 highway, where high traffic intensity occurs, was put into operation in 2006. The road average inclination in the tunnel section is much less than $1 \%$, hence close to zero.

The sampling site choice was conditioned by the need to ensure stable conditions for air sampling. Ideal sampling sites are long road tunnels without active ventilation. The tunnel environment has special characteristics preserving inner air composition due to limited air circulation. The main advantage of road-tunnel studies is that the conditions are well defined and meteorological effects are excluded. Therefore, measurements of emission levels can be obtained under relatively controlled conditions.

\subsection{Measuring system and methods}

The measurements of $\mathrm{NO}_{\mathrm{x}}$ concentrations were carried out using a Horiba AP-360 series air pollution monitoring system. The APNA-360 NOx analyzers are based on the chemiluminescence principle with a low detection limit expressed by a volume fraction of $0.5 \times 10^{-9}$ (Kato and Yoneda, 1997). The nitrogen oxide analyzer uses a multi-flow modulation method that enables synchronic and separate measurements of $\mathrm{NO}, \mathrm{NO}_{\mathrm{x}}$, and $\mathrm{NO}_{2}$. $\mathrm{NO}_{2}$ is determined by subtracting $\mathrm{NO}$ from $\mathrm{NO}_{\mathrm{x}}$ (Kato and Yoneda, 1997). The analyzers were calibrated by an accredited calibration laboratory in the Czech Republic. The sampled air was drawn to the analyzer through a probe and a PTFE (polytetrafluoroethylene) sampling tube, which was equipped with an inlet filter and was positioned in the middle of the road tunnel (Fig. 3).

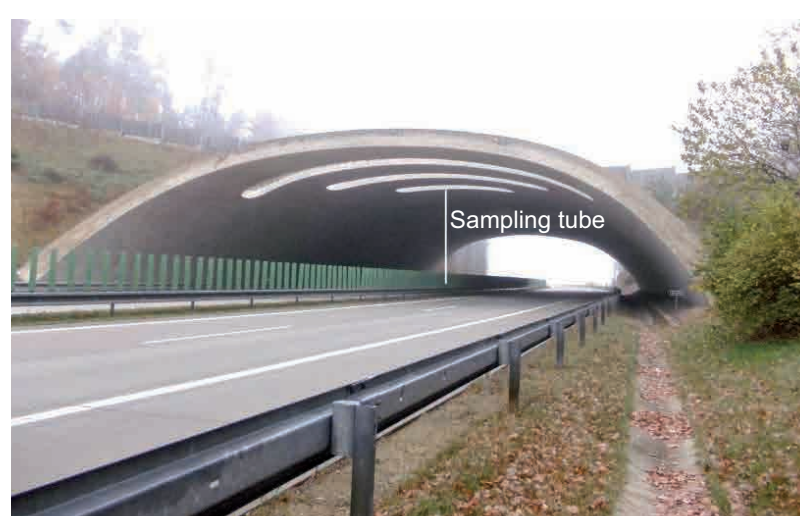

Fig. 3. Designated position for the ambient air sampling in the tunnel environment.

Another part of the measurement consisted in counting the vehicles passing the tunnel section. The assessment of the number of passing vehicles was performed by simple counting. Motor vehicles were divided into two categories: light vehicles (cars and vans with a length up to $6 \mathrm{~m}$ ) and heavy-duty vehicles (trucks and buses).

The sampling time was divided in 9 min intervals comprised of 3 min average values of $\mathrm{NO}_{\mathrm{x}}$. The speed of the vehicles was controlled by calculations and was overwhelmingly equal to the speed limits specified for the measured section of the D11 highway, i.e., $130 \mathrm{~km} / \mathrm{h}$ for light vehicles (LV) and $100 \mathrm{~km} / \mathrm{h}$ for heavy-duty vehicles (HDV). Vehicle speeds during each measurement campaign were controlled and maintained at all meteorological conditions.

\subsection{Modeling of emission factors for NOx tunnel measurements}

To obtain the EFs from tunnel measurements, the HBEFA 3.1 model was implemented. HBEFA 3.1 is a collective of older and new measurements aggregated in an improved model that has access to all existing data. 
To specify the traffic scenario, selected parameters of HBEFA 3.1 were used together with the values listed in Table I. The fleet composition of the passing vehicle proceeds from the PHEM model based on summation of vehicles registered in the countries involved in the HBEFA model setup for the selected years (Hausberger et al., 2009). The fleet parameter "business-as-usual" (BAU) $D$ corresponds to the composition of the vehicle fleet registered in Germany. The BAU $D$ fleet composition parameter was chosen to verify the fleet model in the Czech Republic. This choice acknowledges the fact that the great majority of motor vehicles passing through Czech highways are equipped with the same engines as the vehicle engines in Germany. This assumption applies particularly for the most frequently used Czech vehicle brand, i.e. Škoda.

Table I. Selection of parameters for a specific road traffic case.

\begin{tabular}{ll}
\hline Selected parameters & Requested values \\
\hline Vehicle categories & $\begin{array}{l}\text { Passenger cars (lv) } \\
\text { Heavy-duty vehicles (hv }+ \text { buses })\end{array}$ \\
\hline $\begin{array}{l}\text { Area of traffic } \\
\text { communication }\end{array}$ & Rural \\
\hline $\begin{array}{l}\text { Level of traffic } \\
\text { service }\end{array}$ & Free flow \\
\hline $\begin{array}{l}\text { Speed limit } \\
130 \mathrm{~km} / \mathrm{h}(\mathrm{LV})\end{array}$ & $100 \mathrm{~km} / \mathrm{h}(\mathrm{HV}+\mathrm{Buses})$ \\
\hline Road slope gradient & $0 \%$ \\
\hline Fleet composition & "BAU" $\mathrm{B}$ \\
\hline Selection of years & $2005,2010,2015$ \\
\hline Pollutants & $\mathrm{NO}_{\mathrm{x}}$ \\
\hline
\end{tabular}

\subsection{Data processing}

It is very convenient to apply statistical data processing to tunnel measurements. The experimental results were processed using analysis of variance (ANOVA), which is a method used to test the equality of two or more population means by analyzing the variance of taken samples (Massart et al., 1988). This method makes possible to determine whether the differences between samples are due to either random or systematic errors (Dohnal, 2008). Systematic errors cause the mean in one group to differ from the mean in another. ANOVA is usually used to compare the equality of two or more means (Dohnal, 2008).

\section{Results and discussion}

\subsection{Measurement campaigns and sampling point}

The study was based on short-term daily measurements performed during the years 2015-2018. A total of six successfully completed measurement campaigns, each lasting at least $2 \mathrm{~h}$, were carried out in different weekdays at different hours during the course of the day. The measurements were accomplished under different meteorological conditions and various traffic situations in order to cover the typical traffic condition in the monitored D11 section. Mean wind velocity was below $5 \mathrm{~m} \mathrm{~s}^{-1}$ during all measurement campaigns.

During each of the campaigns, $\mathrm{NO}_{\mathrm{x}}$ concentrations were measured at different heights in the tunnel to specify the sampling point position. The representative sampling point was chosen on the position where the highest concentration of $\mathrm{NO}_{\mathrm{x}}$ was detected. The $\mathrm{NO}_{\mathrm{x}}$ mass concentration dependence on different height positions of the sampling tube is shown in Fig. 4. The sampling point was chosen to be situated at $2 \mathrm{~m}$ above the tunnel ground level in the point where the highest $\mathrm{NO}_{\mathrm{x}}$ concentration was found, as depicted in Fig. 4, for the measurement campaign held on April 13, 2018.

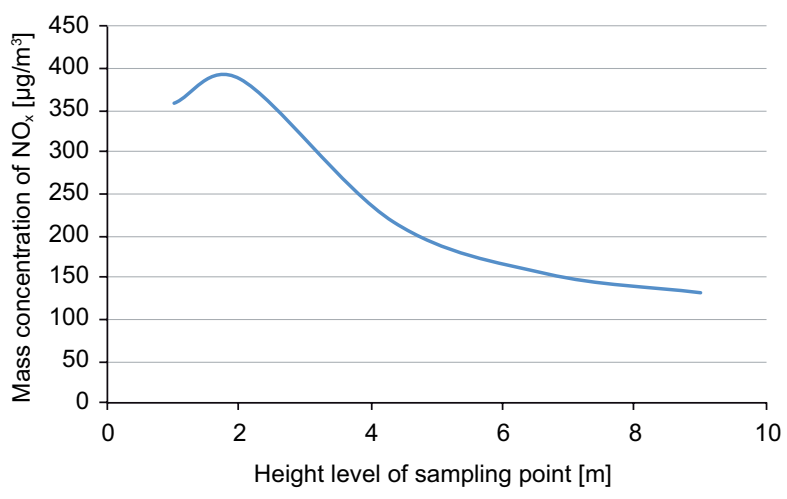

Fig. 4. Height dependence of the $\mathrm{NO}_{\mathrm{x}}$ mass concentration measured in the short tunnel Zeleny most (April 13, 2018). 


\subsection{Time series of the measurement results}

Time series of the concentration progress from the monitored compounds $\mathrm{NO}, \mathrm{NO}_{2}$ and their sum $\mathrm{NO}_{\mathrm{x}}$, were obtained. In figure 5, a typical course of these time series is shown:

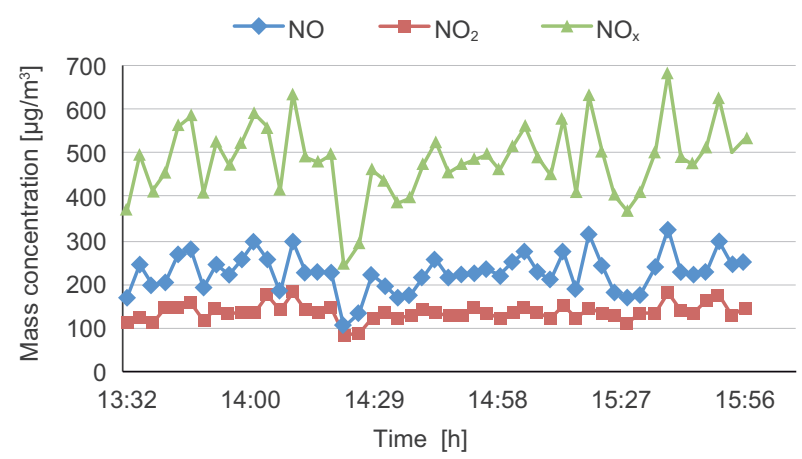

Fig. 5. Temporal variation of the $\mathrm{NO}, \mathrm{NO}_{2}$ and $\mathrm{NO}_{\mathrm{x}}$ mass concentration progress (Zeleny most, April 13, 2018).

The pattern shows that concentrations of $\mathrm{NO}$, $\mathrm{NO}_{2}$ and $\mathrm{NO}_{\mathrm{x}}$ varied during the whole measurement campaign. The actual hourly mass concentration limit of $\mathrm{NO}_{\mathrm{x}}$ at standard conditions $\left(20^{\circ} \mathrm{C}, 101.325 \mathrm{kPa}\right)$ is $200 \mu \mathrm{g} \mathrm{m}^{-3}$ (Czech Republic, 2012). In this context it should be mentioned that during the measuring campaign no time interval was recorded in which the actual $\mathrm{NO}_{\mathrm{x}}$ mass concentration felt below the hourly $\mathrm{NO}_{\mathrm{x}}$ limit.

For the verification of the impact of other $\mathrm{NO}_{\mathrm{x}}$ emission sources in the vicinity of the measuring site, measurements of background $\mathrm{NO}, \mathrm{NO}_{2}$ and $\mathrm{NO}_{\mathrm{x}}$ concentrations were performed. The sampling site was chosen to be at a distance of about $100 \mathrm{~m}$ eastward of the tunnel portal. The resulting values were almost stable and the mean mass background concentration of $\mathrm{NO}, \mathrm{NO}_{2}$ and $\mathrm{NO}_{\mathrm{x}}$ were 21.3, 44.8, and $82.4 \mu \mathrm{g} \mathrm{m}^{-3}$, respectively.

The time series of the ratio of $\mathrm{NO}$ and $\mathrm{NO}_{2}$ mass concentrations observed during all the measurement campaigns were found to be very similar. A typical example of this time series is depicted in figure 6 .

The time series of the number of vehicles (divided into two categories, LV and HDV) passing through the tunnel section were used to assess traffic intensity. The typical course of traffic operations is shown in figure 7 .

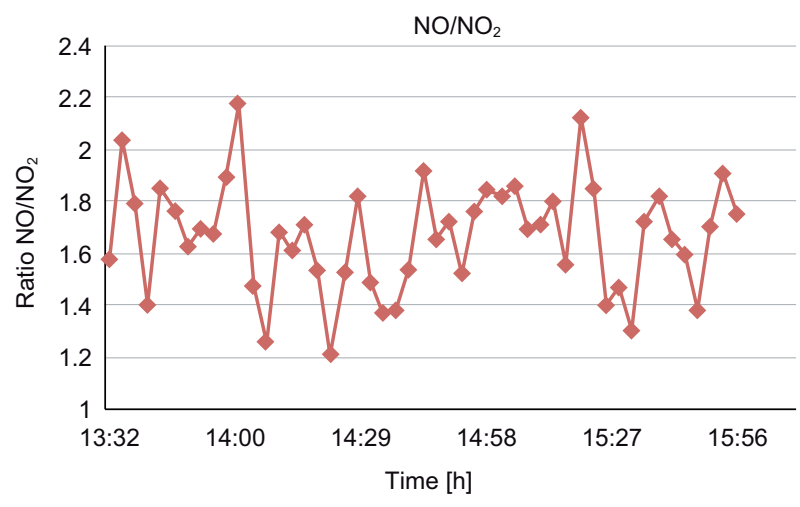

Fig. 6. Temporal variation of the $\mathrm{NO} / \mathrm{NO}_{2}$ ratio (Zeleny most, April 13, 2018).

The measurement campaign held on April 13, 2018 lasted about $3 \mathrm{~h}$ in which high traffic intensity was noticed. The total number of vehicles that passed through the tunnel section of the D11 highway was 4615 . It should be mentioned that during the course of the measuring campaign no time intervals were recorded in which the frequency of LVs felt below 240 crossings. The frequency of HDV s did not fall below five crossings but on the other hand it did not exceed 24 crossings in each 9 min interval.

\subsection{Correlation of $\mathrm{NO}_{x}$ mass concentration and tra-} ffic intensity

An important part of this study was the characterization of the impact of traffic intensity on $\mathrm{NO}_{\mathrm{x}}$ concentration levels in the short tunnel Zeleny most. During the measurements, simultaneous data of time-resolved $\mathrm{NO}_{\mathrm{x}}$ concentrations and passing vehicles calculations were acquired. For the statistical assessment of the correlation of the $\mathrm{NO}_{\mathrm{x}}$ mass concentration generated in the tunnel space and the traffic intensity, analysis of variance was used. Both correlations are graphically expressed in figures 8-10.

The dependence of the $\mathrm{NO}_{\mathrm{x}}$ mass concentration on the number of passing vehicles of different categories (LV, HDV, total number of passing vehicles) was determined. ANOVA compares whether or not the controlled factor has a significant effect (Massart et al., 1988), so it was used to compare whether the number of passing vehicles had a significant effect on the $\mathrm{NO}_{\mathrm{x}}$ mass concentration progress, i.e., a measure 


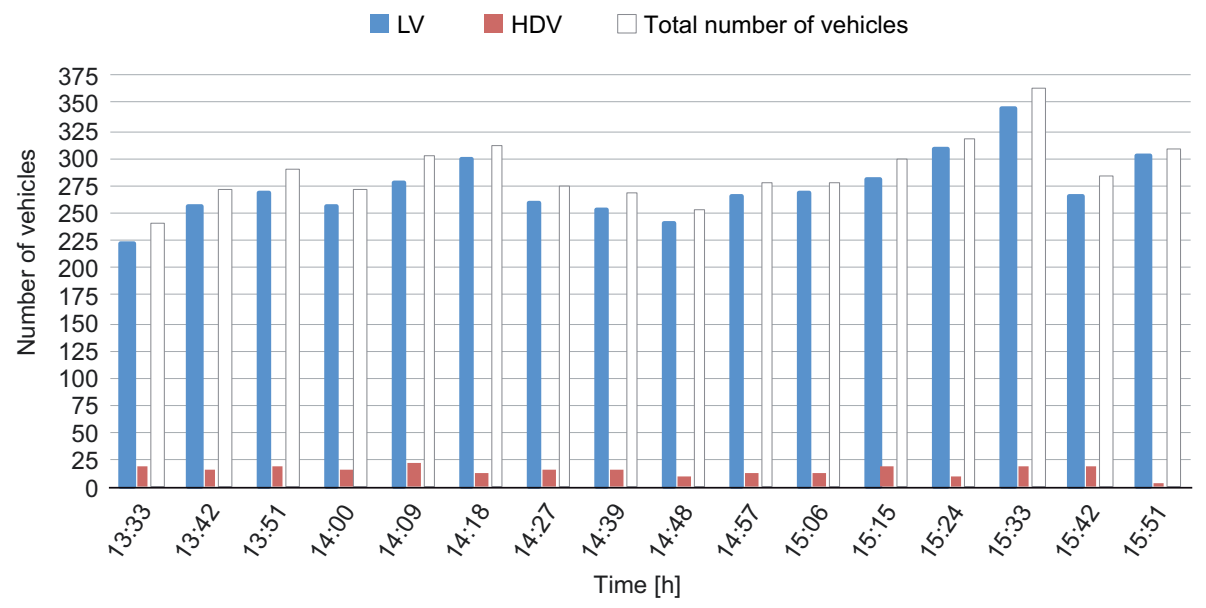

Fig. 7. Total number of vehicles from all categories during the 9-min measurement intervals (Zeleny most, April 13, 2018).

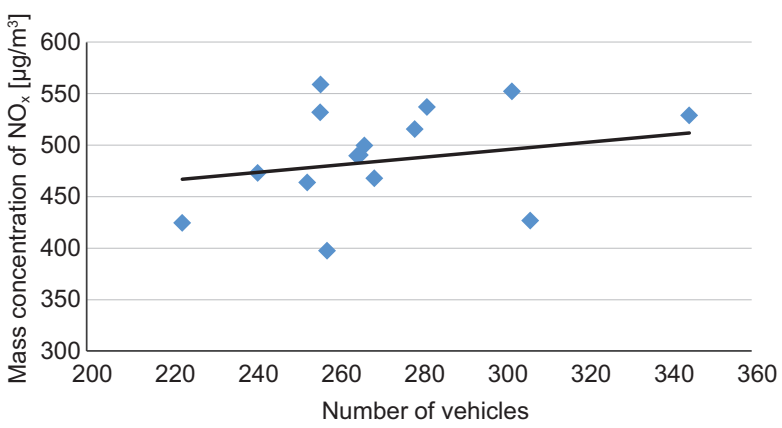

Fig. 8. Correlation of $\mathrm{NO}_{\mathrm{x}}$ mass concentration dependence and number of passing light vehicles in 9-min intervals (Zeleny most, April 13, 2018).

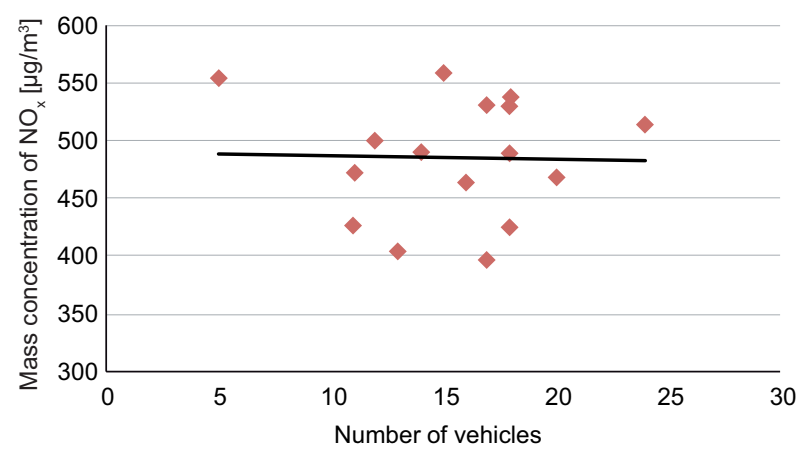

Fig. 9. Correlation of $\mathrm{NO}_{\mathrm{x}}$ mass concentration dependence and number of passing heavy-duty vehicles in 9-min intervals (Zeleny most, April 13, 2018).

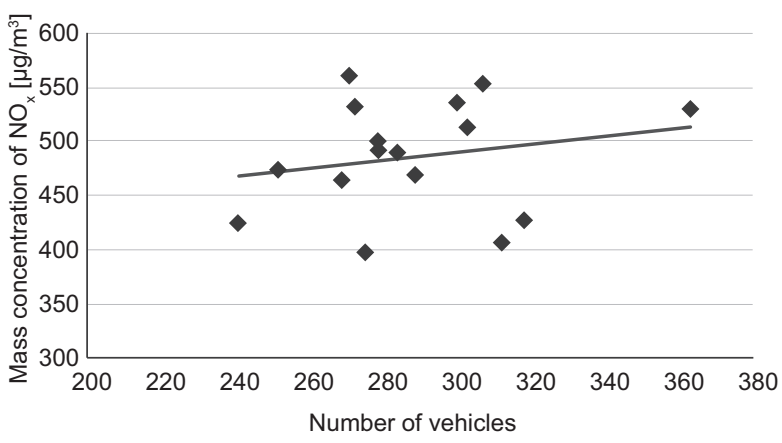

Fig. 10. Correlation of $\mathrm{NO}_{\mathrm{x}}$ mass concentration dependence and number of passing light and heavy-duty vehicles in 9-min intervals (Zeleny most, April 13, 2018).

of linearity. The interpretation of ANOVA is based on the value of the F-test. The linearity test is done by calculating the F-value and comparing it with the tabulated critical F-test value for a given number of degrees of freedom. The results obtained by ANOVA for the example case (April 13, 2018) are depicted in Table II.

In the case of the LV category, the results of all measuring campaigns showed a linear dependency of the mass concentration of $\mathrm{NO}, \mathrm{NO}_{2}$, and $\mathrm{NO}_{\mathrm{x}}$ on the number of passing vehicles. In the case of $\mathrm{HVs}$, the linear dependence of the mass concentration of $\mathrm{NO}, \mathrm{NO}_{2}$, and $\mathrm{NO}_{\mathrm{x}}$ on the number of passing vehicles was not ascertained in all campaigns. The results for HDVs were statistically influenced by the 
Table II. Analysis of variance for example case (Zeleny most, April 13, 2018).

\begin{tabular}{|c|c|c|c|}
\hline \multicolumn{2}{|c|}{ Characteristics of 3-min intervals } & \multirow{2}{*}{$F_{\text {calc }}$} & \multirow{2}{*}{$F_{\text {crit }}$} \\
\hline $\begin{array}{c}\text { Compounds of } \\
\text { interest }\end{array}$ & Vehicle category & & \\
\hline \multirow{3}{*}{ NO } & LV & 1.128 & \multirow{9}{*}{2.02} \\
\hline & $\mathrm{HDV}$ & 1.128 & \\
\hline & Total vehicle sum & 1.131 & \\
\hline \multirow{3}{*}{$\mathrm{NO}_{2}$} & $\mathrm{LV}$ & 1.528 & \\
\hline & $\mathrm{HDV}$ & 1.705 & \\
\hline & Total vehicle sum & 1.501 & \\
\hline \multirow{3}{*}{$\mathrm{NO}_{\mathrm{x}}$} & LV & 1.227 & \\
\hline & HDV & 1.283 & \\
\hline & Total vehicle sum & 1.228 & \\
\hline
\end{tabular}

infrequent number of all individual vehicles compared to the number of LVs, which significantly influenced the value of random variations for this statistic interpretation.

\subsection{Verification of the HBEFA 3.1 model}

The road case of the tunnel section in the D11 highway corresponds to the selection of parameters in HBEFA 3.1. Therefore, this mathematical program was applied to the calculation of the emission factors. The mass of $\mathrm{NO}$ and $\mathrm{NO}_{2}$ (expressed summarily as $\mathrm{NO}_{\mathrm{x}}$ ), corresponding to LVs intensity, monitored and calculated in the tunnel environment, is depicted in figure11. Additionally, figure 11 depicts the $\mathrm{NO}_{\mathrm{x}}$ masses calculated by the HBEFA 3.1 model for passing LVs, corresponding to the fleet structures registered in 2005, 2010, and 2015 in Germany. The results show a significant overestimation of $\mathrm{NO}_{\mathrm{x}}$ emissions calculated by the applied model.

$\mathrm{NO}$ and $\mathrm{NO}_{2}$ masses, expressed summarily as $\mathrm{NO}_{\mathrm{x}}$, corresponding to the HDVs intensity, monitored and calculated in the tunnel environment, are depicted in figure 12. Additionally, figure 12 depicts $\mathrm{NO}_{\mathrm{x}}$ masses calculated by the HBEFA 3.1 model for passing HDVs, corresponding to the fleet structure of this category registered in 2005, 2010, and 2015 in Germany. The results in figure 12 overestimate $\mathrm{NO}_{\mathrm{x}}$ emissions calculated by the applied model for the fleet structure of 2005, and underestimate the fleet structure of 2010 and 2015.

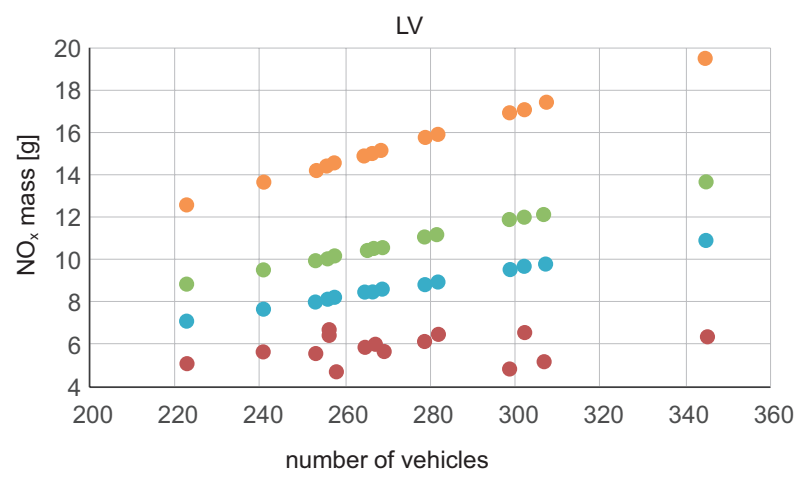

Fig. 11. Comparison of the measured $\mathrm{NO}_{\mathrm{x}}$ mass in each sampling period with the calculated $\mathrm{NO}_{\mathrm{x}}$ mass EFs from HBEFA 3.1 for LVs (Zeleny most, April 13, 2018). Red dots: measured $\mathrm{NO}_{\mathrm{x}}$ mass. Blue dots: $\mathrm{NO}_{\mathrm{x}}$ mass calculated with $\mathrm{EF}$ for 2005. Green dots: $\mathrm{NO}_{\mathrm{x}}$ mass calculated with EF for 2010. Orange dots: $\mathrm{NO}_{\mathrm{x}}$ mass calculated with EF for 2015.

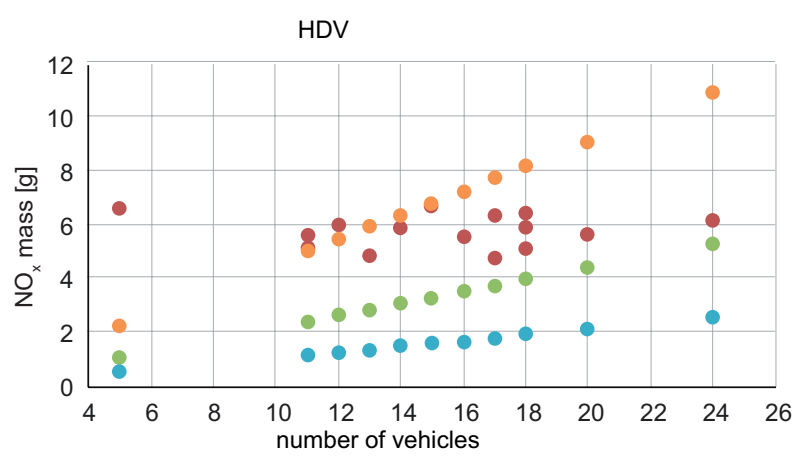

Fig. 12. Comparison of the measured $\mathrm{NO}_{\mathrm{x}}$ mass by sampling period with the calculated NOx mass EFs from HBEFA 3.1 for heavy-duty vehicles (Zeleny most, April 13, 2018). Red dots: measured $\mathrm{NO}_{\mathrm{x}}$ mass. Orange dots: $\mathrm{NO}_{\mathrm{x}}$ mass calculated from $\mathrm{EF}$ for 2005. Green dots: $\mathrm{NO}_{\mathrm{x}}$ mass calculated from $\mathrm{EF}$ for 2010. Blue dots: $\mathrm{NO}_{\mathrm{x}}$ mass calculated from EF for 2015.

\section{Conclusions}

Measurements of $\mathrm{NO}_{\mathrm{x}}$ concentration levels were performed in the road tunnel Zeleny most, Czech 
Republic, in order to verify the impact of traffic intensity and to compare the measured tunnel data with EFs calculated from a comprehensive road traffic emission model. The simultaneous measurement of $\mathrm{NO}_{\mathrm{x}}$ mass concentrations and the count of passing LVs showed a positive linear correlation between the two variables with a correlation coefficient of 0.321 . The simultaneous measurement of $\mathrm{NO}_{\mathrm{x}}$ mass concentrations and the count of passing HDVs showed a slightly negative linear correlation between the two variables with a correlation coefficient of -0.02 . This result may be due to the piston effect generated by the relatively large HDV cross-section passing at high speed through the short tunnel. The results derived from the measurement campaigns were compared to the EFs calculated by the HBEFA 3.1 model for the tunnel case conditions of this study. The results showed an overestimation of NOx emissions calculated using EFs for thr years 2005, 2010, and 2015 with the HBEFA 3.1 model for LVs. The measured NOx emissions are in agreement with the calculated $\mathrm{NO}_{\mathrm{x}}$ emissions using $\mathrm{EF}$ for HDVs in 2005. A considerable underestimation of $\mathrm{NO}_{\mathrm{x}}$ emissions calculated from EFs for the years 2010 and 2015 was found for HDVs. This outcome is emphasized by the fact that, despite all similarities in the fleet composition between the Czech Republic and Germany (section 2.3, Modeling of emission factors for $\mathrm{NO}_{\mathrm{x}}$ tunnel measurements), it can be assumed that the vehicle fleet monitored in the Zeleny most section of the D11 highway consists of slightly older vehicles with less rigorous emission standards than the fleet in Germany. Another fact that can be mentioned regarding the contribution of $\mathrm{NO}_{\mathrm{x}}$ emissions in the tunnel environment, is that HDVs make up only a small part of the total number of vehicles observed in all measurement campaigns (Fig. 7).

The results of the verification measurements carried out in a very short tunnel in the Czech Republic corresponded to the results obtained in other tunnel studies performed under various tunnel conditions and structures (length, non/passive ventilations, single/dual tube structure, different numbers of road lines, different road gradients, etc.). An overestimation of modeled emission factors for road traffic $\mathrm{NO}_{\mathrm{x}}$ emissions has been pointed out in previous works and was confirmed by the results in this work. Further studies are needed in the future on this topic.

\section{Acknowledgments}

The present work was financially supported by IGA VŠCHT (A2_FTOP_2018_018).

\section{References}

Atkinson R. 2000. Atmospheric chemistry of VOCs and $\mathrm{NO}_{\mathrm{x}}$. Atmospheric Environment 34:2063-2101. DOI: 10.1016/S1352-2310(99)00460-4

Barth M, Malcolm C, Younglove T, Hill N. 2014. Recent validation effort for a comprehensive modal emission model. Transportation Research Record: Journal of the Transportation Research Board 1750:13-23.

DOI: $10.3141 / 1750-02$

Beckerman B, Jerrett M, Brook RJ, Verma KD, Arain MM, Finkelstein MM. 2008. Correlation of nitrogen dioxide with other traffic pollutants near a major expressway. Atmospheric Environment 42:275-290.

DOI: 10.1016/j.atmosenv.2007.09.042

Borge R, Miguel I, Paz D, Lumbreras J, Pérez J, Rodríguez E. 2012. Comparison of road traffic emission models in Madrid (Spain). Atmospheric Environment 62:461471. DOI: 10.1016/j.atmosenv.2012.08.073

Brunekreef B, Holgate ST. 2002. Air pollution and health. The Lancet 360:1233-1242.

DOI: $10.1016 / \mathrm{S} 0140-6736(02) 11274-8$

Carslaw CD, Beevers DS. 2005. Estimation of road vehicle primary $\mathrm{NO}_{2}$ exhaust emission fractions using monitoring data in London. Atmospheric Environment 39:167-177. DOI: 10.1016/j.atmosenv.2004.08.053

Chang YT, Suzio JM. 1995. Assessing ozone-precursor relationships based on a smog production model and ambient data. Journal of the Air and Waste Management Association 45:20-28.

DOI: $10.1080 / 10473289.1995 .10467336$

Chen SK, Wang CW, Chen MH, Lin FC, Hsu CH, Kao HJ, Hu TM. 2003. Motorcycle emissions and fuel consumption in urban and rural driving conditions. Science of the Total Environment 312:113-122.

DOI: 10.1016/S0048-9697(03)00196-7

Colberg AC, Tona B, Stahel AW, Meier M, Staehelin J. 2005a. Comparison of a road traffic emission model (HBEFA) with emissions derived from measurements in the Gubrist road tunnel, Switzerland. Atmospheric Environment 39:4703-4714.

DOI: 10.1016/j.atmosenv.2005.04.020

Colberg AC, Tona B, Catone G, Sangiorgio C, Stahel AW, Sturm P, Staehelin J. 2005b. Statistical analysis of the 
vehicle pollutant emissions derived from several European road tunnel studies. Atmospheric Environment 39:2499-2511. DOI: 10.1016/j.atmosenv.2004.07.037 Costabile F, Allegrini I. 2007. Measurements and analyses of nitrogen oxides and ozone in the yard and on the roof of a street-canyon in Suzhou. Atmospheric Environment 41:6637-6647.

DOI: $10.1016 /$ j.atmosenv.2007.04.018

Czech Republic. 2012. Zákon č. 201/2012 Sb. ze dne 2. května 2012 o ochraně ovzduší. In: Sbírka zákonů České Republiky, 69 - 2822. Available at: https://www. zakonyprolidi.cz/cs/2012-201\#cast1 [last accessed on March 19, 2017] [in Czech].

Dohnal L. 2008. Desatero pro porovnáváni výsledkủ dvou metod. Štatistické metódy pro klinickú epidemiológiu a laboratornú prax. Košice, Slovakia: APRILLA s.r.o. Košice pre Knihy Hanzluvka [in Slovakian].

ENVIS. 2009. Mobilní zdroje znečišt'ování ovzduší (REZZO 4 - doprava). Available at: http://envis. praha-mesto.cz/(eayoua45hqweb4i32tpmny55)/zdroj. aspx?typ=2andId $=80004$ andsh $=739976483$ [last accessed on August 7, 2016] [in Czech].

EEA. 2014. Nitrogen oxides (NOx) emissions. European Environment Agency. Available at: https://www.eea.europa. eu/data-and-maps/indicators/eea-32-nitrogen-oxidesnox-emissions-1/assessment.2010-08-19.0140149032-3 [last accessed on March 21, 2017].

Franco V, Kousoulidou M, Muntean M, Ntziachristos L. 2013. Road vehicle emission factors development: A review. Atmospheric Environment 70:84-97.

DOI: 10.1016/j.atmosenv.2013.01.006

Fujita ME, Campbell ED, Zielinska B, Chow CJ, Lindhjem EC, DenBleyker A, Bishop AG, Schuchman GB, Stedman HD, Lawson D. 2012. Comparison of the MOVES2010a, MOBILE6.2, and EMFAC2007 mobile source emission models with on-road traffic tunnel and remote sensing measurements. Journal of the Air Waste and Management Association 62: 1134-1149. DOI: 10.1080/10962247.2012.699016

Gilbert LN, Goldberg SM, Brook RJ, Jerrett M. 2007. The influence of highway traffic on ambient nitrogen dioxide concentrations beyond the immediate vicinity of highways. Atmospheric Environment 41:2670-2673. DOI: 10.1016/j.atmosenv.2006.12.007

Gilbert LN, Woodhouse S, Stieb MD, Brook RJ. 2003. Ambient nitrogen dioxide and distance from major highway. Science of the Total Environment 312:43-46. DOI: 10.1016/S0048-9697(03)00228-6
Hausberger S, Rodler J, Sturm P, Rexeis M. 2003. Emission factors for heavy-duty vehicles and validation by tunnel measurements. Atmospheric Environment 37:5237-5245. DOI: 10.1016/j.atmosenv.2003.05.002

Hausberger S, Rexeis M, Zallinger M, Luz R. 2009. Emission factors from the model PHEM for the HBEFA Version 3. Graz University of Technology, Institute for Internal Combustion Engines and Thermodynamics. Available at: https://www.hbefa.net/e/documents/ HBEFA_31_Docu_hot_emissionfactors_PC_LCV HDV.pdf [last accessed on February 12, 2017].

John C, Friedrich R, Staehelin J, Schläpfer K, Stahel WA. 1999. Comparison of emission factors for road traffic from a tunnel study (Gubrist tunnel, Switzerland) and from emission modeling. Atmospheric Environment 33(20):3367-3376.

DOI: 10.1016/S1352-2310(98)00377-X

Kato J, Yoneda A. 1997. Air pollution monitoring systems AP-360 series. Readout. HORIBA technical reports. Available at http://www.horiba.com/publications/readout/article/air-pollution-monitoring-systems-ap-360-series-147/ [last accessed on February 17, 2017].

Keller M, Wüthrich P. 2014. Handbook emission factors for road transport 3.1/3.2. Quick reference. INFRAS Forschung und Beratung, Bern.

Kim Y, Guldmann JM. 2011. Impact of traffic flows and wind directions on air pollution concentrations in Seoul, Korea. Atmospheric Environment 45:28032810. DOI: 10.1016/j.atmosenv.2011.02.050

Kukkonen J, Härkönen J, Walden J, Karppinen A, Lusa K. 2001. Evaluation of the CAR-FMI model against measurements near a major road. Atmospheric Environment 35:949-960. DOI: 10.1016/S1352-2310(00)00337-X

Last AJ, Sun WM, Witschi H. 1994. Ozone, $\mathrm{NO}$ and $\mathrm{NO}_{2}$ : Oxidant air pollutants and more. Environmental Health Perspectives 102:179-184.

DOI: 10.1289/ehp.94102s10179

Leighton PA. 1961. Photochemistry of air pollution. 1st ed. Academic Press, New York and London.

Lippmann M. 1989. Health effects of ozone: A critical review. JAPCA J. Air Waste Ma. 39:672-695.

DOI: $10.1080 / 08940630.1989 .10466554$

Manahan S, Manahan SE. 2009. Environmental Chemistry. 9th ed. CRC Press, Florida.

Massart D.L., Vandeginste B.G.M., Deming S.N., Michotte Y., Kaufman L. 1988. Chemometrics: A textbook. Elsevier, Amsterdam. 
Menz FC, Seip HM. 2004. Acid rain in Europe and the United States: An update. Environmental Science and Policy 7:253-265. DOI: 10.1016/j.envsci.2004.05.005

Nielsen T, Pilegaard K, Egeløv AH, Granby K, Hummelshøj P, Jensen NO, Skov H. 1996. Atmospheric nitrogen compounds: Occurrence, composition and deposition. Science of the Total Environment 189190:459-465. DOI: 10.1016/0048-9697(96)05246-1

Ollinger VS, Aber DJ, Reich BP, Freuder JR. 2002. Interactive effects of nitrogen deposition, tropospheric ozone, elevated $\mathrm{CO}_{2}$ and land use history on the carbon dynamics of northern hardwood forests. Global Change Biology 8:545-562.

DOI: $10.1046 / j .1365-2486.2002 .00482 . x$

Pattinson W, Longley I, Kingham S. 2014. Using mobile monitoring to visualise diurnal variation of traffic pollutants across two near-highway neighbourhoods. Atmospheric Environment 94:782-792.

DOI: 10.1016/j.atmosenv.2014.06.007

Pirjola L, Paasonen P, Pfeiffer D, Hussein T, Hämeri K, Koskentalo T, Virtanen A, Rönkkö T, Keskinen J, Pakkanen AT, Hillamo ER. 2006. Dispersion of particles and trace gases nearby a city highway: Mobile laboratory measurement in Finland. Atmospheric Environment 40:867-879.

DOI: $10.1016 /$ j.atmosenv.2005.10.018

Prather M, Ehhalt D, Dentener F, Derwent R, Dlugokencky E, Holland E, Isaksen I, Katima J, Kirchhoff V, Matson P, Midgley P, Wang M. 2001. Atmospheric chemistry and greenhouse gases. In: Climate Change 2001: The Scientific Basis (Houghton JT, Ding Y, Griggs DJ, Noguer M, van Der Linden PJ, Dai X, Maskell K, Johnson CA, eds.). Cambridge University Press, Cambridge, 239-287.

Sawyer FR, Harley AR, Cadle HS, Norbeck MJ, Slott R, Bravo AH. 2000. Mobile sources critical review: 1998 NARSTO assessment. Atmospheric Environment 34:2161-2181.

DOI: 10.1016/S1352-2310(99)00463-X

Sayegh A, Tate JE, Ropkins K. 2016. Understanding how roadside concentrations of $\mathrm{NO}_{\mathrm{x}}$ are influenced by the background levels, traffic density, and meteorological conditions using Boosted Regression Trees. Atmospheric Environment 127:163-175.

DOI: $10.1016 /$ j.atmosenv.2015.12.024

Scora G, Barth M. 2006. Comprehensive Modal Emission Model (CMEM), version 3.01. User's guide. Center for Environmental Research and Technology, University of California. Riverside, CA. Available at: https://www. cert.ucr.edu/cmem/docs/CMEM_User_Guide_v3.01d. pdf [last accessed on February 21, 2017].

Seinfeld JH, Pandis SN. 2012. Atmospheric chemistry and physics: From air pollution to climate change. Wiley, New York.

Sjödin Å, Loman G, Omstedt G. 1994. Long-term continuous measurements of air pollutant concentrations, meteorology and traffic on a rural motorway and a model validation. Science of the Total Environment 146-147:365-375.

DOI: 10.1016/0048-9697(94)90258-5

Skácel F, Tekáč V. 2014. Emise z motorových vozidel porovnání součastných evropských modelů. Paliva 6:24-28 [in Czech].

Smit R, Ntziachristos L, Boulter P. 2010. Validation of road vehicle and traffic emission models - A review and meta-analysis. Atmospheric Environment 44:29432953. DOI: $10.1016 /$ j.atmosenv.2010.05.022

US-EPA. 2010. MOVES2010 Highway vehicle population and activity data. EPA-420-R-10-026. U.S. Environmental Protection Agency.

US-EPA. 2015. Official release of EMFAC2014 motor vehicle emission factor model for use in the state of California. U.S. Environmental Protection Agency. Available at: https://www.federalregister.gov/ documents/2015/12/14/2015-31307/official-releaseof-emfac2014-motor-vehicle-emission-factor-modelfor-use-in-the-state-of-california [last accessed on March 20, 2017].

US-EPA. 2016. Description and history of the MOBILE highway vehicle emission factor model. U.S. Environmental Protection Agency. Available at: https://www. epa.gov/moves/description-and-history-mobile-higway-vehicle-emission-factor-model\#main-content [last accessed on February 5, 2017].

Wang X, Westerdahl D, Hu J, Wu Y, Yin H, Pan X, Zhang MK. 2012. On-road diesel vehicle emission factors for nitrogen oxides and black carbon in two Chinese cities. Atmospheric Environment 46:45-55.

DOI: 10.1016/j.atmosenv.2011.10.033

Wang YJ, DenBleyker A, McDonald-Buller E, Allen D, Zhang MK. 2011. Modeling the chemical evolution of nitrogen oxides near roadways. Atmospheric Environment 45:43-52. DOI: 10.1016/j.atmosenv.2010.09.050

WHO. 2000. Air quality guidelines for Europe. 2nd ed. WHO Regional Publications. World Health Organization, Copenhagen (European Series, 91). 